\title{
Basal Cell Hyperplasia
}

National Cancer Institute

\section{Source}

National Cancer Institute. Basal Cell Hyperplasia. NCI Thesaurus. Code C35845.

A pathologic hyperplastic process characterized by the proliferation of the cells of the epithelial layer that resemble the basal cells of the lower part of the epidermis. 